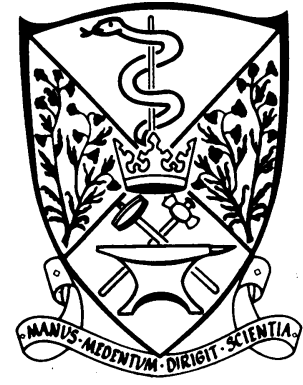

Department of Medicine, Hammersmith Hospital, London W12 0HS Case presented by: D Wynick, MRCP, Wellcome Trust training fellow

Chairman:

C T Dollery, FRCP, professor of medicine

Discussion group:

S R Bloom, FRCP, professor of endocrinology

J M Polak, FRCPATH, professor of histochemistry

J A Lynn, FRCS, consultant endocrine surgeon

Series edited by: Dr Robert Winter.

\title{
Gastrinoma syndrome in multiple endocrine neoplasia
}

\author{
New approaches to localisation and management
}

Multiple endocrine neoplasia type $I$ is associated in $60 \%$ to $70 \%$ of patients with tumours of the pancreatic islet cells, ${ }^{1}$ which, like sporadic tumours of the islet cells, often secrete hormones. Unlike the sporadic tumours, however, multiple endocrine neoplasia type I may be associated with diffuse hyperplasia of islet cells or multiple pancreatic adenomas, or both..$^{23}$ The adenomas may vary in size from a small nest of cells less than $100 \mu \mathrm{m}$ in diameter to an adenoma greater than 2 $\mathrm{cm} .{ }^{3}$ Thus the localisation and management of pancreatic endocrine tumours in patients with the multiple endocrine neoplasia type I syndrome is often difficult, as shown by the presented case.

\section{Case history}

A 46 year old man presented in 1985 with polyuria and proteinuria. Renal biopsy showed membranous glomerulonephritis, and his renal function was impaired (urea concentration $18-20 \mathrm{mmol} / \mathrm{l}$ and creatinine concentration 300-350 $\mu \mathrm{mol} / \mathrm{l}$ ). He was treated with 50 mg prednisolone daily for six months after which the dose was reduced to $15 \mathrm{mg}$ on alternate days (which he subsequently continued). Between 1985 and 1988 he remained well and his renal function was stable, but in 1988 he developed an increased serum calcium concentration of $2 \cdot 80-2 \cdot 95 \mathrm{mmol} / \mathrm{l}$ (corrected to a serum albumin concentration of $40 \mathrm{~g} / \mathrm{l}$ ) and was referred here for investigation. At that time he had a six month history of indigestion and epigastric pain before and after food. His sister had died of a myocardial infarction and had been noted at necropsy to have hyperparathyroidism, and his mother had died aged 42 of a perforated duodenal ulcer.

Physical examination of the patient gave normal results, with no features of chronic hypercalcaemia. The table shows the results of investigations. Because he had never had documented hypocalcaemia and

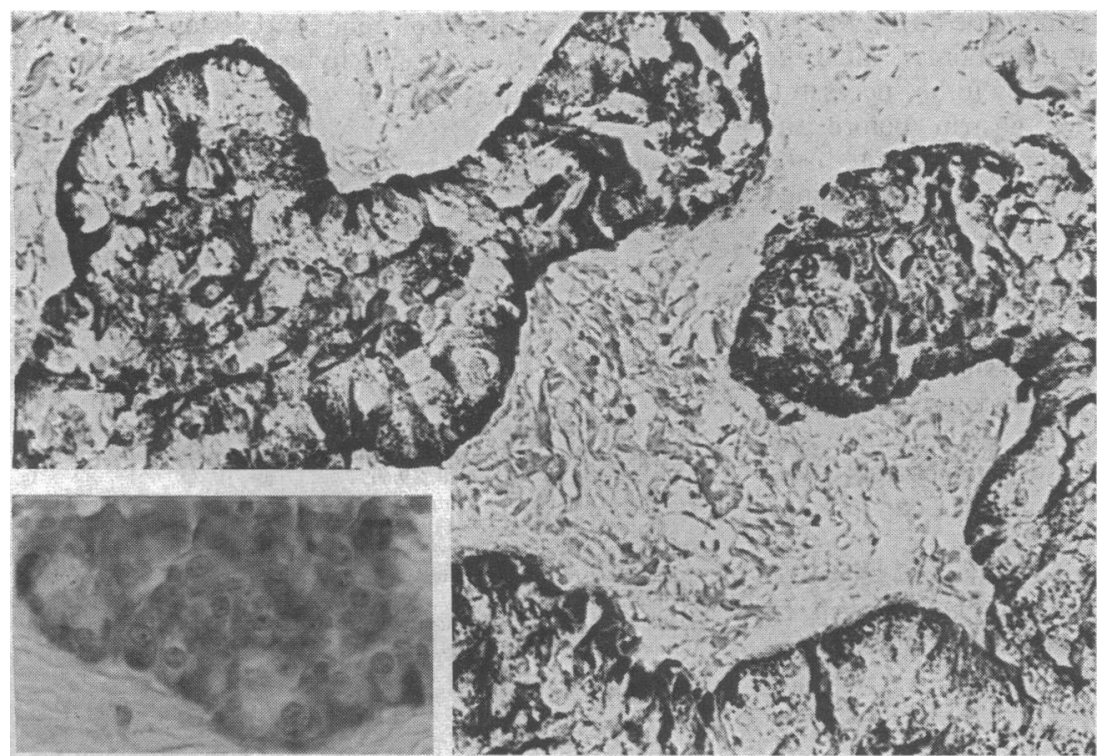

FIG 1-Section of gastrinoma showing positive argyrophilic silver impregnation and indicating highly granulated nature of tumour cells. (Inset) detail of similar section immunostained for glucagon the degree of renal impairment was mild the inappropriately raised parathyroid hormone concentration was thought to represent primary rather than tertiary hyperparathyroidism. Endoscopy showed multiple gastric and duodenal erosions, and his basal acid output was increased, at $18.3 \mathrm{mmol} / \mathrm{h}$ (normal $<5 \mathrm{mmol} / \mathrm{h}$ ). Though the hypergastrinaemia could have been explained by the renal impairment reducing the clearance of gastrin and increasing the basal acid output, the possibility of a gastrinoma could not be excluded. Abdominal computed tomography and highly selective visceral angiography showed a 2 $\mathrm{cm}$ lesion in the middle third of the pancreas, with no visible hepatic metastases.

Results of clinical investigations in patient with multiple endocrine neoplasia type I

\begin{tabular}{lc}
\hline & $\begin{array}{c}\text { Test result } \\
\text { (normal value) }\end{array}$ \\
\hline Full blood count and liver function tests & Normal \\
Urea $(\mathrm{mmol} / \mathrm{l})$ & $19(<7)$ \\
Creatinine $(\mu \mathrm{mol} / \mathrm{l})$ & $365(<120)$ \\
Glomerular filtration rate $(\mathrm{ml} / \mathrm{min})$ & $26-30(120-150)$ \\
Corrected serum calcium $(\mathrm{mmol} / \mathrm{l})$ & $2 \cdot 99(2 \cdot 2-2 \cdot 65)$ \\
Serum phosphate $(\mathrm{mmol} / \mathrm{l})$ & $0 \cdot 69(0 \cdot 8-1 \cdot 4)$ \\
Serum parathyroid hormone $(\mathrm{pmol} / \mathrm{l})$ & $467(44-167)$ \\
Gut hormones: & \\
$\quad$ Vasointestinal peptide, somatostatin, and neurotensin & Normal \\
Pancreatic polypeptide $(\mathrm{pmol} / \mathrm{l})$ & $394(<300)$ \\
Gastrin $(\mathrm{pmol} / \mathrm{l})$ & $162(<40)$ \\
Glucagon $(\mathrm{pmol} / \mathrm{l})$ & $109(<50)$ \\
&
\end{tabular}

In January 1989 the patient's parathyroid glands were removed and for technical reasons he also had a hemithyroidectomy. Subsequent histological examination showed hyperplasia of all four parathyroid glands. Postoperatively, results of tests of his thyroid function and his serum calcium concentration were maintained within the normal ranges by $150 \mu \mathrm{g}$ thyroxine and 1 $\mu \mathrm{g}$ alfacalcidol daily. Despite the introduction of ranitidine $300 \mathrm{mg}$ twice daily and a normal serum calcium concentration he continued to complain of abdominal pain. Ranitidine was therefore withdrawn and omeprazole (a long acting proton pump inhibitor) $40 \mathrm{mg}$ twice daily was started, with good relief of his pain.

In June 1989 the patient was readmitted. His serum calcium concentration and results of tests of thyroid function were within the normal ranges and his renal function was stable (creatinine concentration 356 $\mu \mathrm{mol} / \mathrm{l})$. His serum gastrin concentration, however, was greatly increased at $>400 \mathrm{pmol} / \mathrm{l}$; this could have been partly due to omeprazole, which increases plasma gastrin concentration in half of patients with gastrinomas. ${ }^{4}$ At laparotomy a single $1.5 \mathrm{~cm}$ adenoma in the pancreas was resected. The rest of the pancreas, the liver, and the duodenum appeared normal.

Histological and histochemical examination of the resected adenoma showed positive staining for chromogranin A and neurone specific enolase, both recognised as markers of tumours of islet cells. ${ }^{5}$ Large amounts of glucagon were stored in the tumour (fig 1), and the pattern of granule storage on electron microscopy was consistent with a glucagonoma (fig 2). No positive staining for gastrin was shown. In situ 


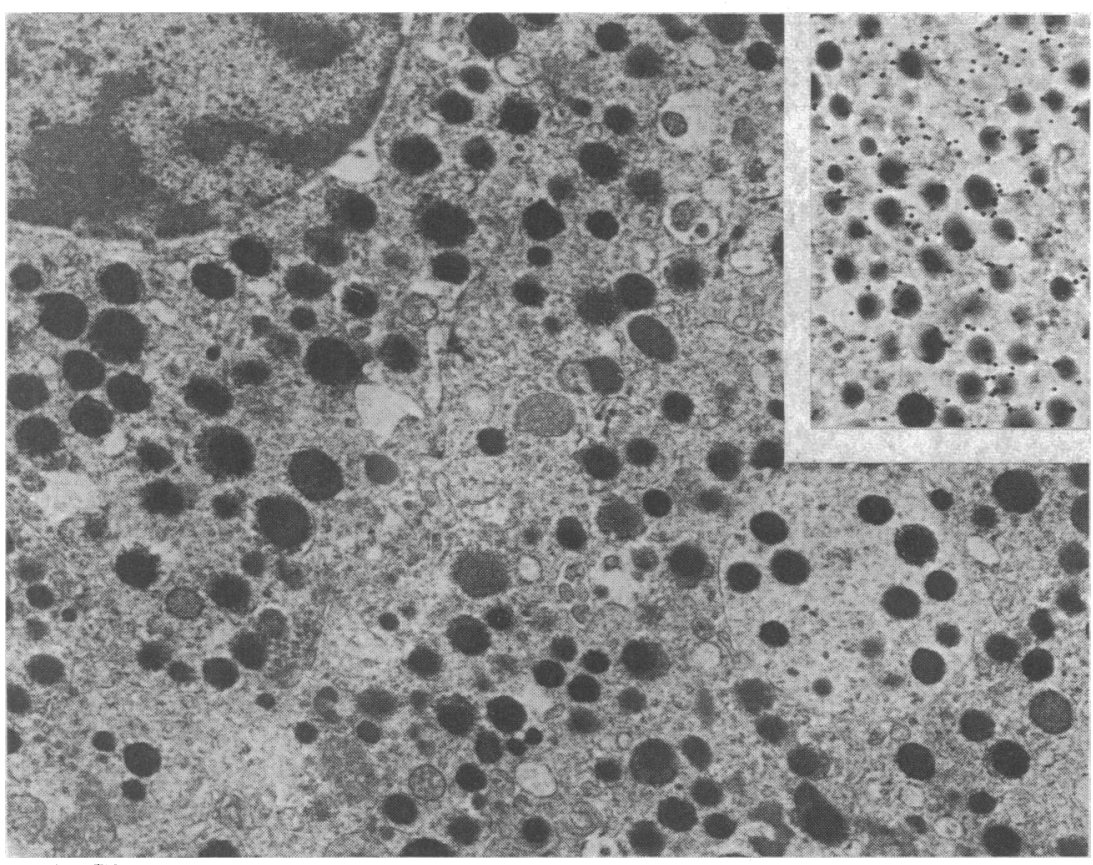

FIG 2-Electronmicrograph of gastrinoma showing many granules with dense eccentric core. (Inset) granules stained for glucagon with immunogold technique the plasma gastrin and glucagon concentrations remained within the normal ranges (concurring with the results of the in situ hybridisation), indicating that the pancreas was producing gastrin ectopically. Before in situ hybridisation techniques were developed the source of gastrin secretion could not have been localised.

\section{Discussion}

SRB: Malignant duodenal gastrinomas may be more common than previously recognised. It is therefore important that when a gastrinoma is suspected the duodenum is also carefully investigated. Unfortunately, as duodenal gastrinomas are often less than $2 \mathrm{~mm}$ in diameter gastroscopy, even in combination with ultrasonography, is unlikely to show the lesion, thus emphasising the need for localisation before the operation. Total pancreatectomy has been advocated when multiple endocrine neoplasia type I is associated with multiple pancreatic adenomas. This, however, is a hazardous operation with a high mortality and morbidity as well as making the patient dependent on insulin and supplements of pancreatic enzymes for life. The unknown incidence of micrometastases is further reason to question the value of this operative approach.

JL: Norman Thompson at Ann Arbor is the only surgeon I am aware of who routinely opens and everts the duodenum to localise and thus remove duodenal gastrinomas.

DW: The published data from Ann Arbor are impressive: they show an $80 \%$ localisation rate and apparent cure (that is, normal plasma gastrin concentrations and no drug treatment) in over three quarters of patients at five years.

SRB: It is interesting that gastrin messenger RNA could be shown in the tumour but not storage of gastrin itself. This would imply hormone synthesis but some failure in the cellular storage mechanism. This is also seen in oat cell tumours of the lung, which often secrete, but do not store, various peptides.

CTD: What is the stability of gastrin messenger RNA, and is it possible that incorrect tumour fixation or storage could degrade the messenger RNA so that it would not hybridise under the conditions used?

JMP: Degradation does occur, which may give a higher background hybridisation or abolish specific hybridisation, thus emphasising the need for fresh tissue, snap frozen in liquid nitrogen.

SRB: Many tumours produce a considerable heterogeneity of messenger RNA sizes, which may further complicate studies on gene expression. Northern blotting as well as in situ hybridisation is useful if sufficient tumour is available.

I Samaan NA, Ouais S, Ordonez NG, Choksi UA, Sellin RV, Hickey RC. Multiple endocrine syndrome type I. Clinical, laboratory findings, and management in five families. Cancer 1989;64:741-52.

2 Thompson GB, van-Heerden JA, Grant CS, Carney JA, Ilstrup DM. Islet cell carcinomas of the pancreas: a twenty-year experience. Surgery 1988;104: 1011-7.

3 Pipeleers-Marichal M, Somers G, Stamm B, et al. Duodenal gastrinomas as a source of hypergastrinemia and Zollinger-Ellison syndrome in patients with multiple endocrine neoplasia type I. N Engl f Med 1990;322:723-7.

4 Havu N. Enterochromaffin-like cell carcinoids of gastric mucosa in rats after life-long inhibition of gastric secretion. Digestion 1986;35 (suppl 1):42-55.

5 Wynick D, Williams SJ, Bloom. SR. Symptomatic secondary hormone syndromes in patients with established malignant pancreatic endocrine syndromes in patients with establish

6 Vinik AI, Thompson N. Controversies in the management of Zollinger-Ellison syndrome. Ann Intern Med 1986;105:956-9.
synd

7 Makowka L, Tzakis AG, Mazzaferro V, et al. Transplantation of the liver for metastatic endocrine tumors of the intestine and pancreas. Surg Gynecol Obstet 1989;168:107-11.

8 Thompson NW, Vinik AI, Eckhauser FE. Microgastrinomas of the duodenum. Ann Surg 1989;209:396-404. the nine months after the pancreatic lesion was resected 